\title{
MULTICRITERION TYPOLOGY OF AGRICULTURE: A SPATIAL DEPENDENCE APPROACH
}

\author{
Benicjusz GŁęBocki, Ewa Kacprzak, Tomasz Kossowski \\ Adam Mickiewicz University, Poznań, Poland \\ Manuscript received: January 21, 2019 \\ Revised version: March 25, 2019
}

\begin{abstract}
GŁęвоскі B., KAстRZAK E., KossowsKi T., 2019. Multicriterion typology of agriculture: A spatial dependence approach. Quaestiones Geographicae 38(2), Bogucki Wydawnictwo Naukowe, Poznań, pp. 29-49. 1 table, 3 figs, 2 appendices.

AвSTRACT: At the turn of the 21st century Polish agriculture intensively changed as the consequence of: 1) the socio-economic transformation that started in 1989, 2) the general transition from a centrally-planned economy to a market economy and 3) Poland's accession in 2004 to the European Union. In this paper, we try to describe, in a synthetic way, the spatial heterogeneity of development of agriculture in Poland. For this purpose we identified the types of contemporary Polish agriculture. We applied the measures of global (Moran 1950) and local (LISA) spatial autocorrelation devised by L. Anselin (1995) and used their calculations in classification methods. Our dataset consists of 69 variables and 3,069 spatial units at the LAU2 level. As the result of the analysis we identified 20 types of agriculture in Poland and presented their characteristic features. We have paid particular attention to a spatial distribution of identified types. We concluded that the distribution is not only a result of natural or socio-economic conditions and local spatial relationships, but also to a greater extent is still affected by historical conditions (mainly partitions and changes of borders after the First and Second World Wars).
\end{abstract}

KEY wORDS: agriculture, typology of agriculture, multicriterion typology of agriculture, Poland

Corresponding author: Tomasz Kossowski, Institute of Socio-Economic Geography and Spatial Management, Adam Mickiewicz University, Poznań, ul. B. Krygowskiego 10, 61-680 Poznań, Poland; e-mail: tkoss@amu.edu.pl

\section{Introduction}

One of the most important and long-lasting research trends in the field of agricultural geography is an attempt at the synthetic approach to the spatial issue of agriculture in various spatial scales (Aitchison 1986/2014, 1992/2014; Bertaglia et al. 2007; Blazy et al. 2009; Carmona et al. 2010; Falkowski, Kostrowicki 2001; Gregor 1970; Grigg 1966, 1969, 1974, 1995; Hudson, White 2007; Iraizoz et al. 2007; Kostrowicki 1968, 1972, 1977, 1991; Kostrowicki, Szyrmer 1990; Köbrich, Rehman et al. 2003; Scott 1983; Singh 1979; Szczęsny 1982, 1988; Tittonell et al. 2010; Tschudi, Johanson 1983; Tyszkiewicz 1982; Whittlesey 1936). The typology and regionalisation of agriculture are the research interest of both agricultural geographers and agricultural economists. Proposed agricultural classifications have greatly contributed to the understanding of agricultural systems functioning in the world and to the development of agricultural geography as a regular science (Aitchison 1986/2014).

Agriculture is a complex system that consists of numerous components closely related to one another. For this reason, various criteria are adopted in the works synthesising spatial systems of agriculture. Falkowski and Kostrowicki (2001) point out that the following conditions are taken into account: 1) natural conditions of agricultural development (for the most part agricultural regions are identified with the areas 
of similar natural conditions for agricultural development), 2) external conditions of agriculture (mainly natural) and selected features of agriculture, 3) one dominating element of agriculture in a given area (e.g. dominant crop), 4) a selected group of elements of agriculture, prevailing in the studied area, and 5) the synthetic characteristics of agriculture (possibly comprehensive). At the same time many different synthetic concepts are used (including a region, a system, a type) as well as methods enabling a synthetic characterisation of agriculture. The multiplicity of research approaches used in the geography of agriculture makes it difficult to compare the results.

The criteria and methods used in the classification of agricultural systems are subject to a multi-aspect assessment, e.g. Aitchison 1986/2014, 1992/2014, Falkowski and Kostrowicki (2001), Gregor (1970), Grigga (1969), Kostrowicki (1972), Mądry et al. (2011), and Wysocki (2010). An indepth analysis of problems related to the classification of agricultural systems was conducted by Aitchinson (1986/2014, 1992/2014). He distinguished 4 stages of the classification process. The first stage in the process of the classification of agricultural systems is a research context in which the proposed classification is determined. The research context includes description, explanation, methodology, and prescription. The second stage is the "Scale of Analysis" and is related to design. In this stage, we identify taxonomic units (e.g. fields, farms, farmers) and attributes to be used in the classification. The next step is analytical and includes the selection of the classification method. The procedure ends with a step called: "Interpretation and evaluation of typological structures and spatial patterns". In this step, the typology is evaluated in the context of the adopted research objectives. It should be emphasised that the basic problems of the typology of agriculture are: the availability of statistical data, the selection of diagnostic variables and the selection of methods.

The work carried out by the the International Geographical Union Commission for Agricultural Typology in the 1960s and 1970s under the leadership of J. Kostrowicki was extremely important in the development of the classification of agricultural systems in the geography of agriculture. During that work, a set of conditions which the typology of agriculture should fulfill were defined, and a detailed methodology of typology was also described. This typology should only rely on the internal characteristics of agriculture described by 28 variables. These variables were defined as measures and grouped in four categories: social ${ }^{1}$, operational ${ }^{2}$, production ${ }^{3}$ and structural $^{4}$. The type of agriculture was defined as a notion, being a synthesis of the features adopted (e.g. Kostrowicki 1964, 1977, 1979; Agricultural Typology and Land Use 1973; Agricultural Typology and Land Utilisation 1975).

In the Polish agricultural geography, intensive research on the typology of agriculture was conducted from the 1960s to the early 1990s. It was carried out at different levels of spatial aggregation: regional, national, and global, as well as taking into account various European countries and regions. (e.g. Bański 1991; Biegajło 1968, 1973; Falkowski 1977; Gałczyńska 1982, 1985;

1 - percentage of total agricultural land held in common, 2 - percentage of total agricultural land in labour and share tenancy, 3 - percentage of total agricultural land in private ownership, 4 - percentage of total agricultural land operated under collective or state management, 5 - number of active workers per agricultural holding, 6 - area of agricultural land per holding (hectares), 7 - gross agricultural production per agricultural holding.

28 - number of active agricultural workers per 100 ha of agricultural land, 9 - number of draught animals per 100 ha of cultivated land, 10 - number of tractors, harvesters, etc. in terms of total horsepower per 100 ha of cultivated land, 11 - chemical fertilisers: NPK per hectare of cultivated land, 12 - irrigated land as a percentage of total cultivated land, 13 - harvested land as a percentage of all arable land (including fallow), 14 - livestock units per 100 ha of agricultural land.

15 - gross agricultural production per hectare of agricultural land, 16 - gross agricultural production per hectare of cultivated land, 17 - gross agricultural production per active agricultural worker, 18 - gross commercial production per active agricultural worker, 19 - commercial production as a percentage of gross agricultural production, 20 - commercial production per hectare of agricultural land, 21 - degree of specialisation in commercial production.

22 - perennial and semi-perennial crops as a percentage of total agricultural land, 23 - grassland (permanent and temporary) as a percentage of total agricultural land, 24 - food crops as a percentage of total agricultural land, 25 - livestock production as a percentage of gross agricultural production, 26 - commercial livestock production as a percentage of gross commercial production, 27 - gross production of industrial crops as a percentage of total agricultural production, 28 - herbivorous livestock as a percentage total livestock. 
Głębocki 1979, 1986; Kostrowicki 1964, 1970, 1978; Kostrowicki, Szczęsny 1978; Matusik 1973; Stola 1970, 1972, 1974, 1977; Szczęsny 1978, 1981, 1982, 1988; Szyrmer 1984; Tyszkiewicz 1977, $1979,1982,1986)^{5}$.

The last attempt at the typology of agriculture in Poland (at the local level LAU2 - communes) was done by Szczęsny (1988). It concerned the role of individual farming under the planned economy. Later, a synthetic typology of Polish agriculture was abandoned (Bański 2007a), although at the turn of the 21st century Polish agriculture intensively changed as the consequence of: 1) the socio-economic transformation which started in $1989,2)$ general transition from a planned economy to a market economy and 3) Poland's accession in 2004 to the European Union.

In our study, we identified types of agriculture in Poland and, to this purpose, a new method of typology was also proposed. We also identified conditions and factors determining the types of Polish agriculture. Particularly, we paid a special attention to historical conditions.

R. Szczęsny and R. Szczęsny (1996, 81.11), analysing the types of agriculture identified at the end of the 1980s, found that "In 1988 types of agriculture were spatially heterogenous, according to spatial heterogeneity of Polish agriculture at that time." and "After 70 years of independence and some diverse development within the interwar period and last 45 years, there are still clear borders of the former partitions (17721918), where the development of agriculture in the nineteenth century was influenced by other socio-economic systems". In this paper, we try to verify whether those observations are still valid for the types of Polish agriculture developed at the beginning of 21 st century.

\section{Conditions and factors determining the types of agriculture in Poland after 1945}

The specific spatial distribution of the types distinguished is a result of many factors and determinants (Fig. 1). Kostrowicki (1969)

\footnotetext{
The scientific output of the Polish geography of agriculture in the field of the typology of agriculture was comprehensively discussed in the papers: The scientific output of agricultural geography in Poland (2005) and in Falkowski, Kostrowicki (2001).
}

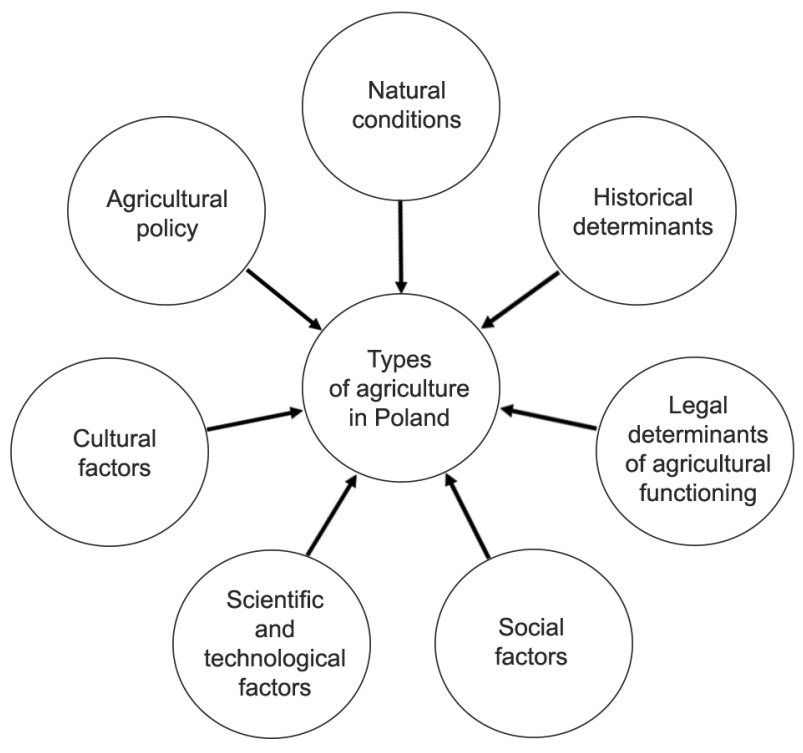

Fig. 1. Conditions and factors determining the types of agriculture in Poland after 1945. Source: own elaboration.

emphasised that every type of agriculture is the result of the interaction of social, technical, economic and cultural processes. These processes are developing at a specific time and place and in specific natural conditions. The most significant among the external factors is the historical one - the fact that for almost 150 years Polish territory was partitioned among three different states: Russia, Prussia and Austria (Fig. 2). Although this situation ended after the First World War, traces of the specific partition can still be observed, especially in rural areas. What also greatly contributed to spatial differences in agriculture were the radical modifications in Poland's borders after both world wars which brought about deep systemic, social and economic changes. Especially great changes took place after the Second World War. As a result of agreements concluded by three world powers, Poland's territory shifted westwards as far as the Oder river and its left-bank tributary, the Lusatian Neisse, while in the east its boundaries were set by the longitudinal section of the Bug river. The north-eastern boundary is artificial in nature. In the south, Poland's territory is closed by the mountain ranges of the Carpathians and the Sudeten, and in the north, by the Baltic Sea (Czapiewska 2003; Głębocki 2007b; Grykień 2005; Jezierski, Leszczyńska 2003; Morawski 2011; Musiał 2012; Olszewski 1985; Sroka 2015; Woś 1998; Stola, Szczęsny 1976). 


\begin{tabular}{|l|}
\hline Legend \\
Territory of Poland in 1772 \\
Russian part of Poland in 1815-1914 \\
German part of Poland in 1815-1914 \\
$\square$ Austrian part of Poland in 1815-1914 \\
- - Boundary in 1934 \\
- Boundary in 2018 \\
i-- Regions in 2018 \\
- Main cities in regions
\end{tabular}

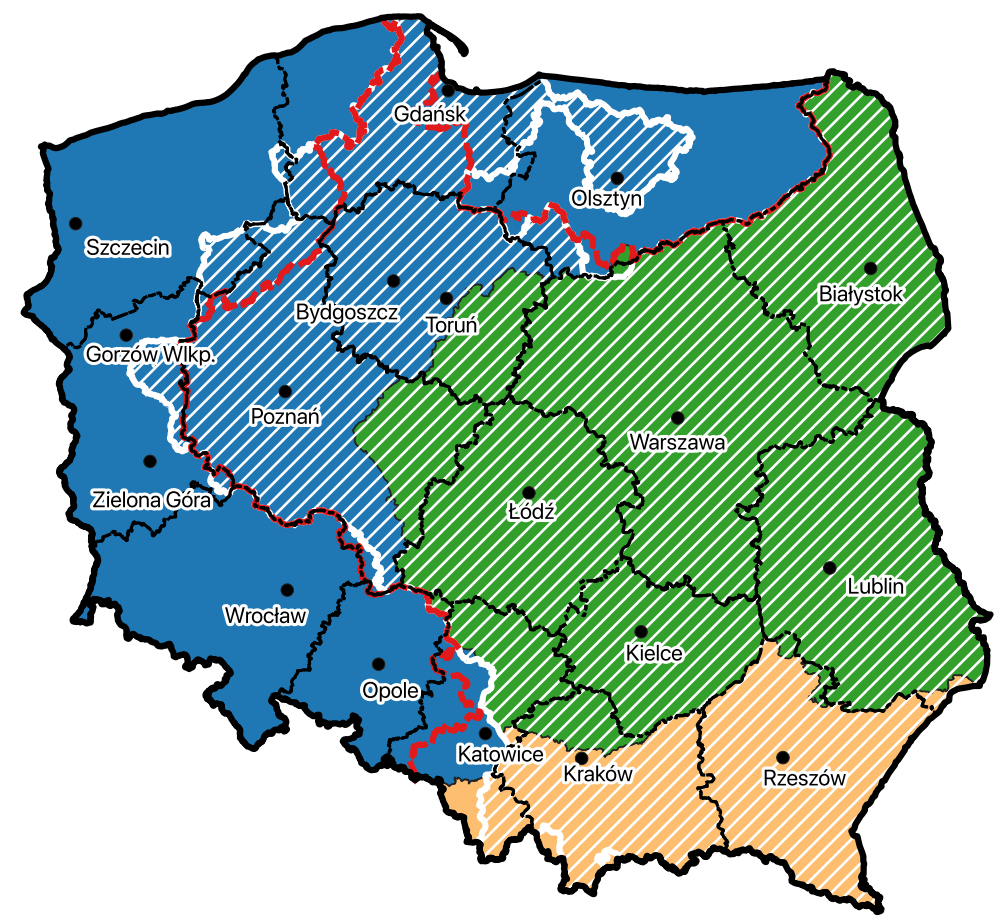

Fig. 2. Polish borders in 1772-2018. Source: own elaboration.
Changes in the borders also caused largescale migratory movements. Poles who lived in the old eastern borderland until the end of the Second World War were moved to Poland's new north-western regions left by the displaced German population (Gawryszewski 2005). Rural areas there were usually well-equipped (for those times) with technical infrastructure, but it was often unknown to people arriving from the previous eastern borderland, which caused its rapid depreciation. In an agricultural reform, the state took over all farmland left by the Germans, and people settling in rural areas were given only a limited acreage to organise private farms. Even so, not all land resources were disposed of. On disused land various types of state farms were gradually organised. The years 1949-1956 were a period of intensive collectivisation of Polish agriculture that in fact arrested its development (Atlas rolnictwa Polski 2010; Bański 2007a; Jezierski, Leszczyńska 2003; Morawski 2011; Kaliński, Noniewicz 2015). It should be noted that until the systemic changes of 1989, the state's agricultural policy was highly variable. It usually tended to be unfavourable for the development of private farming. Favourable changes took place only during cyclic food management crises accompanied by people's discontent.
However, such periods were short (Głębocki 2000, 2014).

The systemic changes introduced in 1989 and the economic restructuring that accompanied them caused Polish agriculture to enter a new development path. At first this development was halted by the opening of boundaries, the transition to a market economy and the liquidation of state farms and some cooperative ones. This brought about an increase in unemployment in areas where they were located. After this stage had ended, with the financial assistance of the European Union countries, the situation in rural areas started to improve gradually. Further beneficial changes took place after Poland's accession to the EU. The more ample financial means it obtained then greatly contributed to the rapid development of agriculture, thus causing the emergence of new patterns of its types (Głębocki 2006, 2007b, c; Jezierska-Thole, Janzen, Rudnicki 2014; Kłodziński, Wilkin 1999; Polska wieś... 2016; Przestrzenna transformacja... 1998; Rudnicki 2010, 2013a, b, 2014).

It should also be observed that, apart from historical, political, economic and social factors, what greatly influences the formation of the specific types of agriculture and their spatial distribution is natural conditions (Atlas obszarów... 2016, Atlas rolnictwa Polski 2010, Bański 2007a,b; 
Charakterystyka rolniczej przestrzeni produkcyjnej... 2003; Głębocki 2007a, b; Kopiński, Krasowicz 2010; Kulikowski 1986, 2007a, b; Rolnictwo na obszarach specyficznych 2013; Stankowski 2007; Stola, Szczęsny 1976).

\section{Data and methods}

The analysis was carried out on a set of 3,069 spatial units and a large set of variables (69) describing agriculture in Poland. These spatial units correspond to the LAU 2 (NUTS 5) level and are official administrative units in Poland with its own self-government management. The set of variables is a result of Agricultural Census in 2010 and, additional data were obtained from Head Office of Geodesy and Cartography in Warsaw.

Variables can be divided into 5 groups: 1) the land tenure system and the organisation of the production space, 2) labour resources and quality, 3) means of production, 4) natural resources, the structure of crops and animal husbandry, 5) effects of agricultural production (Appendix 1,2).

Due to the limited volume of the article, only the interpretation possibilities of the research results for the features included in the first group are shown (Table 1).

The typology of agriculture can be identified in many different ways. Usually, a simple cluster

Table 1. Land tenure system (2012) and the organisation of the production space (2010).

\begin{tabular}{|c|c|c|c|c|c|c|c|c|c|c|c|}
\hline \multirow{3}{*}{1} & \multirow{3}{*}{2} & \multicolumn{10}{|c|}{ Typological features } \\
\hline & & \multicolumn{6}{|c|}{ Land tenure system } & \multicolumn{4}{|c|}{ The organisation of farms } \\
\hline & & 3 & 4 & 5 & 6 & 7 & 8 & 9 & 10 & 11 & 12 \\
\hline Poland & 3069 & 7.3 & 65.2 & 14.0 & 0.8 & 0.7 & 2.2 & 7.9 & 35.1 & 9.2 & 12.7 \\
\hline 1 & 128 & 1.6 & 92.2 & 3.7 & 0.1 & 0.2 & 0.2 & 3.1 & 34.5 & 12.3 & 13.6 \\
\hline 2 & 106 & 4.7 & 86.2 & 4.1 & 0.5 & 0.6 & 0.9 & 6.0 & 30.6 & 11.6 & 13.4 \\
\hline 3 & 156 & 12.6 & 69.0 & 4.3 & 3.1 & 1.7 & 2.4 & 5.0 & 39.9 & 19.6 & 23.7 \\
\hline 4 & 52 & 10.8 & 66.6 & 5.0 & 0.7 & 1.1 & 9.0 & 5.7 & 36.3 & 20.2 & 27.3 \\
\hline 5 & 230 & 1.7 & 88.8 & 5.8 & 0.2 & 0.3 & 0.5 & 5.1 & 32.8 & 8.4 & 9.6 \\
\hline 6 & 67 & 1.8 & 59.2 & 23.0 & 0.3 & 0.5 & 2.5 & 15.3 & 20.1 & 7.3 & 9.5 \\
\hline 7 & 99 & 1.1 & 76.1 & 18.3 & 0.2 & 0.2 & 0.5 & 7.3 & 28.6 & 4.0 & 5.2 \\
\hline 8 & 132 & 9.4 & 70.5 & 8.8 & 1.4 & 0.6 & 2.4 & 3.9 & 54.5 & 9.9 & 14.3 \\
\hline 9 & 93 & 2.1 & 83.0 & 11.3 & 0.5 & 0.2 & 0.4 & 3.8 & 41.0 & 6.7 & 8.0 \\
\hline 10 & 174 & 1.5 & 83.4 & 10.3 & 0.3 & 0.2 & 0.6 & 5.8 & 31.8 & 5.3 & 6.3 \\
\hline 11 & 92 & 2.8 & 73.8 & 16.8 & 0.5 & 0.3 & 0.6 & 7.4 & 29.3 & 3.6 & 4.7 \\
\hline 12 & 74 & 0.9 & 68.1 & 25.1 & 0.1 & 0.5 & 0.5 & 6.9 & 41.8 & 2.4 & 3.7 \\
\hline 13 & 116 & 4.3 & 58.9 & 23.7 & 0.9 & 0.8 & 1.3 & 10.8 & 30.5 & 2.9 & 5.0 \\
\hline 14 & 76 & 4.5 & 43.8 & 30.5 & 1.4 & 1.1 & 1.6 & 13.9 & 32.2 & 3.1 & 6.6 \\
\hline 15 & 129 & 1.3 & 67.6 & 25.5 & 0.3 & 0.6 & 0.5 & 12.2 & 19.4 & 2.2 & 3.4 \\
\hline 16 & 89 & 3.5 & 46.0 & 38.8 & 0.5 & 0.5 & 1.3 & 17.2 & 21.8 & 1.5 & 3.1 \\
\hline 17 & 216 & 23.1 & 53.3 & 7.1 & 0.4 & 0.8 & 7.6 & 6.1 & 43.7 & 20.2 & 28.5 \\
\hline 18 & 146 & 21.0 & 57.6 & 5.3 & 3.1 & 0.5 & 6.0 & 3.8 & 58.7 & 14.8 & 22.6 \\
\hline 19 & 125 & 14.3 & 52.7 & 10.7 & 0.6 & 0.6 & 3.9 & 8.2 & 38.8 & 8.2 & 14.7 \\
\hline 20 & 769 & 7.0 & 52.2 & 17.7 & 0.5 & 1.1 & 1.8 & 10.3 & 31.9 & 8.4 & 12.7 \\
\hline
\end{tabular}

Column number:

1 - number of type of agriculture.

2 - number of territorial units.

3 - percentage of the Treasury property.

4 - percentage of natural persons' property (farms).

5 - percentage of natural persons' property (building lots).

6 - percentage of farming cooperatives' property.

7 - percentage of churches and denominational associations' property.

8 - percentage of companies' property.

9 - percentage of consolidated agricultural land in farms.

10 - percentage of agricultural land in farms with more than 10 plots.

11 - average area of all farms in ha,

12 - average area of farms over 1 ha.
Contributions of features in types of agriculture:

\begin{tabular}{|r|c|}
\hline 1 & determining \\
\hline 0 & neutral \\
\hline-1 & minimal \\
\hline
\end{tabular}


analysis is conducted or one of the many classification methods on a large or small dataset describing agriculture in given regions, countries or any other units. However, if we consider agriculture as a phenomena related to human activity, we also should notice its spatial context. The problem is, that the most popular methods are "blind" to the spatial dimension of agriculture. Particularly, methods used in the typology do not take into account the effects like: proximity of spatial units and their agricultural activity, neighbourhood effect or just spatial heterogeneity. As a consequence, a new method is necessary and this method should also measure the influence of spatial effects on the distribution of agriculture types across regions or countries. Especially, spatial dependence is considered as a leading effect that affects the spatial distribution of different types of agriculture.

We developed and implemented a new procedure for a typology of agriculture. It had several steps, and the first one was the identification of spatial dependence in data describing agriculture in spatial units analysed. The next step of the typology was the detection of spatial clusters, i.e. finding groups of spatial units satisfying two kinds of proximity: in the type of agricultural activity and location proximity (understood as "being neighbours in space"). The last step is a final typology of agriculture with the use of classification methods. As it was mentioned above, the typology was conducted on the set of Polish communes as an example.

The spatial dependence is one of the spatial effects and was formally defined by Anselin (1988). This effect assumes that relationships between neighbouring spatial units are much more stronger than between distant ones (Tobler 1970; Kossowski 2018). We can measure how processes or phenomena in one spatial unit influence those in the neighbouring spatial units.

A concept of the spatial weights matrix is the most popular solution for presenting a neighbourhood structure. The most basic spatial weights matrix is a binary and symmetric matrix. We define a weight $c_{i j}$ as equal to one if objects $i$ and $j$ are neighbours, and as zero otherwise. We also assume, that two spatial units (regions, countries) are neighbours when they share a common boundary. However, the problem is that spatial relationships are usually non-symmetric and a spatial weights matrix should contain information about this fact. The reason for non-symmetric spatial relationship is that spatial units are not homogenous as well as they have different potential to interactions. This problem was solved by Cliff and Ord (1973) in the way of a row-standardised matrix $\mathbf{W}$, and its solution is very popular. More advanced studies on spatial weights matrices were done, for example, in papers by Tiefelsdorf, Griffith and Boots (1998), Getis and Aldstadt (2004) and many more.

The spatial weights matrix presented can be used for a spatial autocorrelation analysis of data. The spatial autocorrelation measure was formulated by Moran (1950) and is widely applied for geographical datasets. Although this measure was defined for a symmetric, binary spatial weights matrix, it is also commonly used for a row standardised spatial weights matrix $\mathbf{W}$. The formula for Moran's I is as follow:

$$
I=\frac{\sum_{i=1}^{n} \sum_{j=1}^{n} w_{i j}\left(x_{i}-\bar{x}\right)\left(x_{j}-\bar{x}\right)}{\sum_{i=1}^{n}\left(x_{i}-\bar{x}\right)^{2}}
$$

where $w_{i j}$ are elements of a spatial weights matrix, $x_{i}$ are observations, $n$ is the number of spatial units. Positive spatial autocorrelation is for values of $\mathrm{I}>-\frac{1}{n-1}$ and results in clustering pattern on the map. Otherwise we can detect negative spatial autocorrelation and, as its consequence, a chessboard pattern across the set of analysed regions. When the spatial autocorrelation measure is close to $-\frac{1}{n-1}$ we have a random distribution of variables on the map.

Standardised Moran's I measure Z $(I)$ is a significance test for spatial autocorrelation. In this paper, we followed a permutation approach. The values of variables were $k$ times permuted on the map, and for each permutation Moran's Z(I) statistic was calculated. The number of permutations, $k$, is usually larger than the number of spatial units on the map. A result of the procedure is an empirical distribution of Moran's Z $(I)$ with an empirical $p$-value.

Coming to the second step of our analysis, we have to mention, that Moran's I measures only a global spatial autocorrelation pattern. If we want to find an area, where spatial units are locally 
under stronger positive or negative spatial dependence, we have to use Local Indicators of Spatial Association introduced by Anselin (1995). Among these indicators, one is local Moran's statistic. We can identify two kinds of clusters: 1) with high values of variables, also known as Hot Spots, surrounded by regions with high values too, or 2) low values of the analysed variables, socalled Cold Spots, also with neighbours with low values of variables. Clusters are determined at significance $p<0.05$. Results can be drawn on the LISA map. Details of the method, i.e. how to interpret values, and how to assign a spatial unit to a cluster or to interpret as an outlier, are described in Anselin (1995). As the result of this step, each spatial unit is described by the vector of length equal to the number of the variables analysed. If the spatial unit belongs to Hot Spot regarding a particular variable, then the element of the vector related to this variable is equal to one. In the case of Cold Spot, the element is equal to -1 . If it is neither Hot Spot nor Cold Spot, then the element is equal to 0 . As a result of the LISA method, each spatial unit is described using a 69-component vector (of length equal to the number of variables) consisting of the values: $-1,0,1$.

For the transformed data related to spatial units, the third step of analysis, i.e. cluster analysis was performed using the $k$-means method. In this procedure the set of spatial units was divided into an arbitrarily chosen number of classes. The characteristics of each class was done by analysing the vectors of spatial units included in each class. If a given variable was dominated by the value " 1 " in the vector, then we assumed that the variable has a high positive description in the characteristics of the class and, if the predominant values are " -1 ", then it is assumed that the variable has a high negative description. If the vector elements for the variable under consideration took mainly " 0 ", or had big variance, it was assumed that the variable does not describe the analysed class. This resulted in the identification of 20 types of agriculture in Poland.

\section{Spatial distribution and characteristics of the types of agriculture in Poland}

Using the mentioned methodology we conducted a typology of agriculture in Poland. For this purpose, we gathered data on agriculture in Poland which consist of 69 variables. Then, we conducted an analysis of spatial autocorrelation of these variables. All variables had a statistically significant Moran's I. It confirmed the presence of spatial dependence. The values were calculated using Moran's I for a row-standardised matrix $\mathbf{W}$. Some of these variables (exactly 23) had a very high spatial autocorrelation, exceeding the level of 0.5 . Such a large number of variables with a very high spatial autocorrelation show a high spatial concentration of administrative units similar to each other.

The distinguished types differ in the proportion of variables characterising them, or by their absence. Their spatial distribution is specific. Those found in north-western Poland are more uniform and make up clusters embracing a large number of territorial units. In turn, in the areas that used to be Russian and Austrian partitions the differences in the types are wider; also, the clusters of uniform territorial units that they form are smaller (Fig. 2, 3).

The characterisation of the distinguished types of agriculture was based on a deeper analysis of the average values of variables used in the research. The types were assigned numbers from 1 to 20 . While subjective, this numbering also describes them in a way.

\section{Types of agriculture with a dominance or higher share of private farms}

Types 1-6 differ in their genesis, spatial distribution, internal organisation, and directions of agricultural production, but they all have a high share of farms owned by natural persons. Those are predominantly commercial farms, hence most of them give work in agriculture as the main source of income.

Type $\mathbf{1}$ has formed in Podlasie, in its central and western parts, where it passes into the north-eastern areas of Mazovia (Fig. 3). This cluster also includes a narrow belt of WarmiaMazuria territorial units neighbouring in the north and east with those regions. This type is characterised by a predominance of individually-owned holdings in the ownership structure $(92.2 \%)$, and of medium-sized farms in the size structure (averaging 13.6 ha AL). The agricultural education of farm heads there is higher 


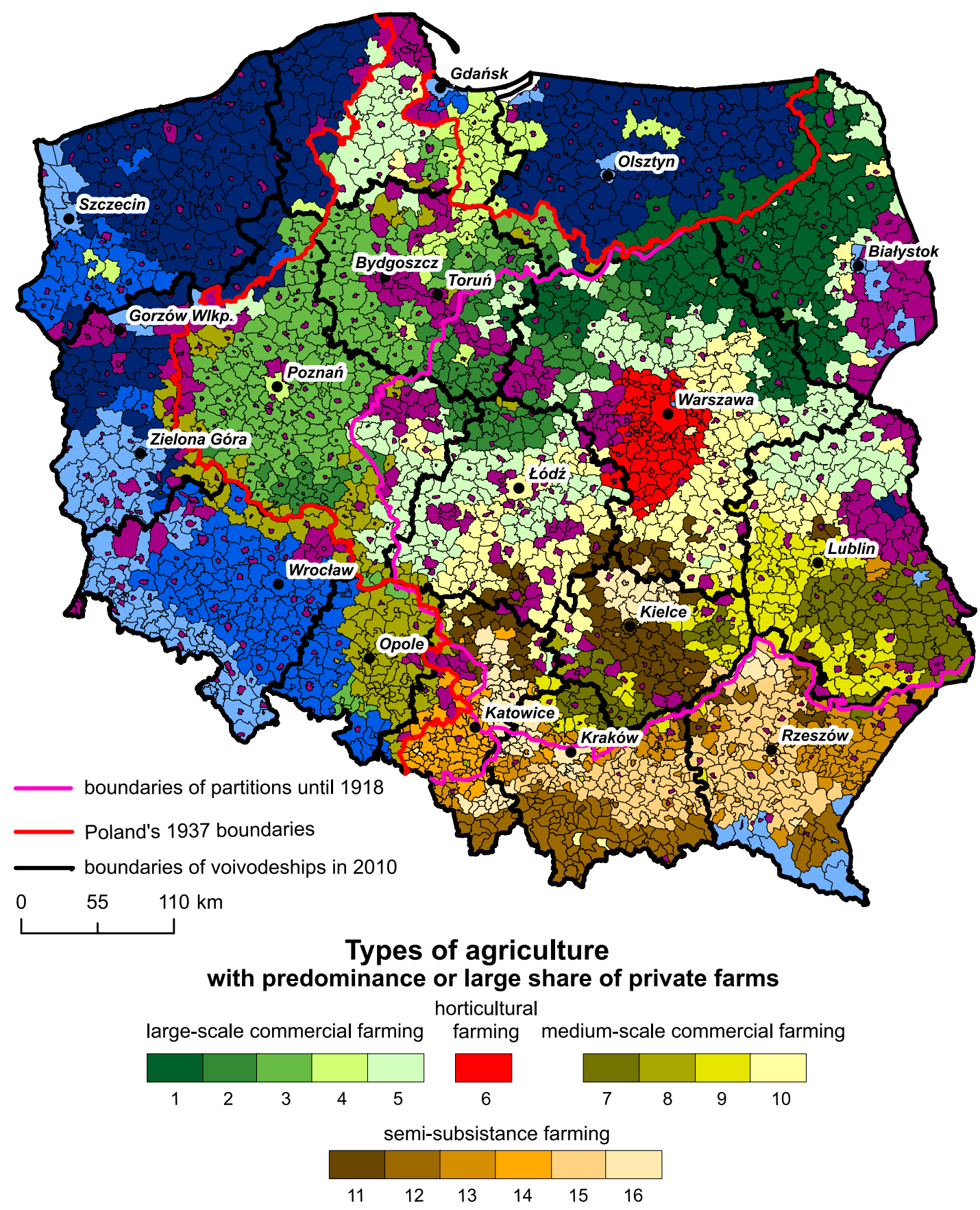

with large share of big farms representing various forms of ownership

medium-scale and

semi-subsistence farming

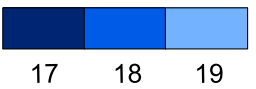

of various genesis

semi-subsistence farming

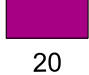

Fig. 3. Types of agriculture in 2010.

Source: own elaboration. 
than the mean for Poland. Their age structure is favourable, as shown by the low share of farm operators in the post-working age group $(4.7 \%)$. Equipment with machinery largely depends on the kind of agricultural production conducted. The poor soil quality is responsible for the fact that arable land occupies $54.8 \%$ of farmland ${ }^{6}$, and because of the local water conditions permanent grassland is an important use here ${ }^{7}$. Predominant in the crop structure are cereals (80.5\%), and among them the less demanding forage species. In animal production ${ }^{8}$ the leading role is played by dairy cattle ${ }^{9}$. A characteristic of this type is the highest proportion of holdings in which more than $50 \%$ of earnings are obtained from work in agriculture $-54.5 \%{ }^{10}$. A mere $7.5 \%$ of holdings declare that disability and old-age pensions exceed $50 \%$ of their incomes ${ }^{11}$.

Type 2 is characteristic of 106 territorial units mostly situated in the central part of the country. It appears in a few clusters as well as in some dozen territorial units forming a small concentration in the south of Wielkopolska region. This type has developed in areas where soil conditions are favourable for agriculture. Mediumsized individually-owned farms predominate here $(86.2 \%)^{12}$. The other forms of farmland ownership are of secondary significance. The level of agricultural education of farm operators is higher than the national mean, and their age structure is favourable. In the structure of farmland, arable land predominates (85.7\%). Farms of this type assign a considerable part of the cultivated area to sugar beets $(4.6 \%)$ and vegetables $(3.1 \%)^{13}$. Animal production is at a good level, especially the husbandry of cattle and swine. As to earnings, $56.0 \%$ of farms obtained more than $50 \%$ of

The national mean being $67.3 \%$.

Meadows occupy $30.0 \%$ of $\mathrm{AL}$, and pastures $11.9 \%$. Those are the highest figures in the types distinguished (the national means amounting to $17 \%$ and $4.2 \%$, respectively).

8 The stocking rate of cattle per 100 ha AL in 2010 was 95.3 head, including 51.8 cows.

9 This is the most important milk-producing region in Poland.

10 This is the highest value of this indicator among all the types distinguished. The national mean equals $22.9 \%$.

11 The national mean being $16.4 \%$.

12 Their mean size is 13.4 ha AL.

13 The national means being $2 \%$ and $1.3 \%$, respectively. them from agricultural activity, while disability and old-age pensions were the main source of income in $8.3 \%$ of holdings.

Type 3 is characteristic of a large part of Wielkopolska region and the western parts of the neighbouring one, Kujavia-Pomerania. In the latter, there are two narrow branches extending from this large compact cluster. The bigger, easterly one, extends as far as the south-western part of Warmia-Mazuria, and the smaller, northerly, discontinuous one, goes into Pomerania. This whole area was in the Prussian partition until the First World War. Typical of the ownership structure of farmland there is a high proportion of holdings owned by natural persons ${ }^{14}$. Those are usually big farms, their mean area exceeding 23,7 ha. A considerable part is owned by the Treasury $(12.6 \%)$ and cooperative farms. In comparison with the other types, churches and denominational associations constitute a significant proportion of farmland owners. Employment per 100 ha AL is low for the Polish conditions, at 14.4 persons ${ }^{15}$. Agriculture of this type is characterised by good equipment with the means of production and a high consumption of artificial fertilisers $(161.5 \mathrm{~kg}$ of a pure NPK component / ha AL). The most important in the crop structure are wheat $(18.2 \%)$, triticale $(17.0 \%)$, barley (13.3\%), and rape (13.6\%). This type stands out for its high stocking rate of swine - 232 head /100 ha AL.

Type 4 has developed in areas of a specific nature. It can be found almost exclusively in Żuławy Wiślane in Pomerania and WarmiaMazuria regions, and in areas connected with the Lower Vistula valley in Kujavia-Pomerania. It embraces the smallest number of territorial units (52). In comparison with the previous types, individually-owned farms are less significant in the ownership structure $(67.8 \%)$, while the shares of the Treasury $(10.9 \%)$ and commercial companies $(10 \%)$ are greater. This type is characterised by large farms, their average size being 23.6 ha AL. The level of agricultural education of farm operators is good, as demonstrated by $3.3 \%$ of persons with higher agricultural education ${ }^{16}$ and one of the lowest indicators of those with no such

14 In Poland this term is used with reference to farms owned by individual persons.

15 The indicator is lower only in type 4 (11.8 persons per 100 ha AL).

16 This is the highest figure in all the types distinguished. 
education $-37.9 \%$. Because of its high quality, the share of wheat in the crop structure of type 4 is the highest among the types distinguished $42.3 \%$. Of great significance among crops is rape, which occupies $21.4 \%$ of the total sown area ${ }^{17}$. In turn, animal production is poorly developed.

Type 5 has developed in areas with worse soil conditions. It shows a high level of scattering. It can be found mainly in highly fragmented clusters in the central and eastern parts of the Central Polish Lowland. There is also a large compact cluster of this type in Pomerania, where it embraces territorial units largely inhabited by Kashubians. In the ownership structure individually-owned farms predominate (89\%). The agricultural education of farm heads is better than the national average. Also more favourable is their age structure as expressed, e.g. by a low share of farm operators in the post-working age group ${ }^{18}$ $(5.57 \%)$. Predominant among field crops are cereals $(76.2 \%)$, especially triticale $(19.7 \%)$, mixed cereals $(18.8 \%)$, and rye $(17.2 \%)$. Other crops of major significance are potatoes and maize for green fodder. In animal production, the best developed is the husbandry of cattle and swine, and in the case of poultry, of geese ${ }^{19}$. The chief sources of their incomes are agricultural activity $(36.8 \%)$ and work for hire $(25.6 \%)$. The proportion of holdings for which the chief source is disability and old-age pensions is low $-10.2 \%$.

Type 6 embraces a compact area of 65 territorial units in Mazovia and 2 neighbouring ones in Łódź region. It has developed under the influence of the large, absorptive market of Warsaw for products of vegetable origin. This is a sort of a feeding zone for the city. In the farmland ownership structure small individually-owned farms predominate ${ }^{20}$. The nearness of Warsaw has caused private farmland there to perform housing, recreational and service functions (14.2\% AL). The educational level of farm operators is above the national average, but their age structure is worse than the mean for the country. This type stands out for a very high proportion of orchards $-33.7 \%$, while important field crops are potatoes $(11.6 \%)$ and vegetables

17 The national means for those crops were $20.5 \%$ and $9.1 \%$, respectively.

18 Over 65 years old.

19 The stocking rates of those animals were 53.9, 124.1 and 91.1, respectively, per 100 ha AL.

20 In 2010 their average size was 6.64 ha AL.
$(10.5 \%)^{21}$. A significant role is played by crops under glass. The indicator characterising this type of cultivation, $6,695.8 \mathrm{~m}^{2} / 100$ ha of arable land, is more than ten times higher than the national mean of $644.7 \mathrm{~m}^{2}$. Against such an intensive vegetable production, animal husbandry is of secondary significance. This type has also the highest proportion of holdings involved exclusively in commodity production $(29.4 \%)^{22}$. This high level of commodification shows in the fact that $32.2 \%$ of holdings gave work in agriculture as their chief source of income. And because of the nearness of Warsaw, for $22.1 \%$ of holdings the chief source of income was work for hire.

\section{Types of medium-scale farming}

Type 7 can be found in upland areas where it occurs in three compact clusters. The largest is situated on the Lublin Upland, and the two smaller ones on the Sandomierz Upland and in the borderland between Świętokrzyska Land and Małopolska, where it embraces the Miechowska Upland and the Proszowicki Plateau. Those regions have favourable soil conditions. In this type individually-owned farms predominate in the ownership structure $(82.3 \%)$. There is also a high proportion of private property that is not farmland $(11.4 \%)$. The average size of holdings is slightly bigger than in the two previous types (7.9 ha AL), but they are more fragmented. In the structure of agricultural land arable land predominates $(82.6 \%)$. Because of its high quality, important crops are those with demanding soil requirements: wheat $(38.6 \%)$, barley $(17.8 \%)$, rape $(5.7 \%)$, and sugar beets $(5 \%)$. In this type there is a very high proportion of farms conducting agricultural activity $(95.9 \%)$, but also showing a low level of commodification ${ }^{23}$. The chief sources of income are farming (37.2\%) and work for hire (23\%).

Type 8 is characteristic of the north-eastern Silesian Lowland in Opole region and the neighbouring small fragments of Silesian, Łódź and Wielkopolska regions, where it forms a compact cluster. There are also specific, narrow branches extending from this concentration in the northerly

${ }^{21}$ The national means being $2.4 \%$ and $1.3 \%$, respectively.

22 The national mean being $14.6 \%$.

$2310.1 \%$ of holdings are chiefly involved in commodity production. 
direction. The western branch is continuous and embraces communes situated on both sides of the 1918-1938 Polish-German border. The eastern branch is less distinct and not continuous, but clearly follows the pre-1918 boundary between the Prussian and Russian partitions. Typical of those frontier areas was a mixture of nationalities of the population living there. According to the 2002 Population Census, 106.9 thous. of its inhabitants $(10 \%)$ were of German nationality. In the ownership structure, individually-owned holdings predominate $(71.8 \%)$. Those are usually medium-sized farms ${ }^{24}$ characterised by great land fragmentation. Over $50 \%$ of agricultural land belonged to holdings possessing it in more than 10 separate pieces. The share of the Treasury in farmland ownership is significant $(10.4 \%)$. The use of artificial fertilisers is high for the Polish conditions $(175.1 \mathrm{~kg}$ of a pure NPK component /ha AL). The leading role in plant production is played by cereals $(78.3 \%)$, and in their internal structure, wheat $(18.5 \%)$, triticale $(15 \%)$, and barley $(14.3 \%)$. Among other crops rape is the most important $(9.4 \%)$. In animal production, a high stocking rate per 100 ha $\mathrm{AL}$ is recorded in the case of swine (196.4 head) and poultry $(2,734.7$ head $)^{25}$. Over $85 \%$ of holdings conduct agricultural activity. Their earnings come primarily from two equivalent sources - agricultural activity $(26.9 \%)$ and work for hire $(26.3 \%)$.

Type 9 has developed in loess areas. It occurs in the south-western part of Lublin region, in a small cluster of territorial units located west of the Vistula valley in Świętokrzyska Land and Mazovia, as well as in a small area with similar natural determinants in the north of Małopolska. This type is characterised by a high share of private property ${ }^{26}$, the predominance of small holdings (5.3 ha AL on average), as well as high employment in agriculture (57.9 persons /100 ha AL). Over $52 \%$ of farm holders do not have any agricultural education. The number of tractors is high - 16.4 per 100 ha of AL (national average is 9.5). Because of the natural determinants ${ }^{27}$, this type has a high share of orchards in the structure

\footnotetext{
In 2010 their average size was 12.96 ha AL.

The national mean being 1,000/100 ha AL.

26 Individually-owned holdings possessed $79.6 \%$ of agricultural land. $15.8 \%$ of their area was lots performing housing, recreational and service functions.

27 Good soils and areas with favourable sun exposure.
}

of farmland (10.2\%), and as to field crops, vegetables play an important role $(4.6 \%)$. This type stands out for well-developed bee-keeping ${ }^{28}$. In spite of the high proportion of holdings conducting agricultural activity (88.7\%), only $10.9 \%$ are exclusively involved in commodity production, while $16.1 \%$ work to satisfy their own needs. Because of the small farm area and the destination of production, $27.9 \%$ of holdings give work for hire as the chief source of their income, and $23.9 \%$ indicate work in agriculture. Besides, for $17.7 \%$ of holdings the chief sources of income are disability and old-age pensions.

Type 10 is characteristic of Mazovia (its south-eastern part) and the southern part of Łódź region, where it occurs in highly fragmented clusters. In the eastern part of Mazovia it passes into Lublin region, where it forms a small compact cluster between Puławy and Lubartów. Small and medium-sized individually-owned farms predominate here ${ }^{29}$, the other forms of ownership being less significant, with the exception of lots that are not farms ${ }^{30}$. In the crop structure cereals predominate $-75 \%$, of which rye accounts for $23.2 \%$, mixed cereals for $18.2 \%$, and triticale for $18.1 \%$. Among other crops potatoes are the most important (4.2\%). A characteristic feature of this type is the great significance of crops under glass $-3,014.4 \mathrm{~m}^{2} / 100 \mathrm{ha}$ of arable land. There is a high proportion of holdings conducting agricultural activity, but only $14.5 \%$ of them earmark their production mainly for the market. As to their chief sources of income, $31.3 \%$ came from work for hire, and $21.6 \%$ from agricultural activity.

\section{Types of semi-subsistence farming}

Types 11-16 occur only in the southern part of Poland in the areas of the former Austrian Partition and partly in the Russian part. Today the agricultural function tends to disappear fast here, which is caused by factors of a socio-economic nature, especially those connected with urbanisation, industrialisation, and the development of services, but also with an increase in the society's wealth. They have many features in

288.6 bee colonies per 100 ha $\mathrm{AL}$, the national average being 3.8 colonies.

29 Individually-owned farms accounted for more than $85 \%$ of AL, while their average size was 6.29 ha AL.

30 They owned $9.3 \%$ of agricultural land. 
common, but they also differ in details following from historical and natural determinants, and from the geographical location.

Type $\mathbf{1 1}$ is characteristic of Świętokrzyska Land and Silesia as well as the neighbouring small fragments of Łódź and Mazovia regions. In addition to these areas, they can be found in small dispersed clusters in Lublin and Subcarpathia regions. In Świętokrzyska Land it is characteristic of the Nida Basin, and in Silesia, of its upland areas. The quality of soils is highly diversified, but poor ones predominate. Predominant in the ownership structure are small, individually-owned farms, and a large share of farmland belongs to housing-recreational lots $^{31}$. Among field crops the leading ones are cereals $(73.1 \%)$. A significant role is also played by potatoes $(6.3 \%)$. The level of animal production is low. The high proportion of farms conducting agricultural activity $(78.6 \%)$ goes with a low level of their commodification $^{32}$. The chief sources of income are work for hire $(27.8 \%)$ and disability and old-age pensions $(19.4 \%)$, while in only $12.3 \%$ it is work on one's own farm.

Type 12 is characteristic of the Carpathian mountain areas. It occurs in two clusters. The larger one embraces the southern part of Małopolska and a small fragment of Silesia, and the smaller one is in Subcarpathia region, north of the Bieszczady Mountains. Those are areas with a relief difficult for agriculture, but unusually attractive in landscape terms. Hence in areas with type 12 agricultural activity tends to disappear fast. In the structure of farmland ownership, private property predominates. Most holdings conduct agritourist activity. Those are small farms, with an average area of 3.9 ha AL and high land fragmentation ${ }^{33}$. Over $21 \%$ of agricultural land belongs to persons who use it for non-agricultural purposes. This type is characterised by high employment (71.5 persons /100 ha AL), a low level of agricultural education of farm heads, and their unfavourable age structure. Arable land occupies a mere 12.9\% of its area, the dominant uses being permanent

31 Individually-owned holdings had $77.1 \%$ of agricultural land, and housing-recreational lots, $15.1 \%$.

32 Only $8.6 \%$ of holdings earmark their production mainly for the market, and over one-fourth $(26.5 \%)$ exclusively for their own needs.

33 Those are areas with traditional family divisions of farms. grassland - meadows (58.1\%) and pastures $(8 \%)$. In the crop structure cereals predominate, but the most important crop is potatoes $-28.6 \%$. As to animal production, before the transition to the market economy in 1989 this was an area of the husbandry of cattle and sheep. Today cattle husbandry is only conducted to satisfy the holdings' own needs, and sheep husbandry has largely disappeared. In sum, the proportion of holdings that do not conduct agricultural activity is high, their commodification is low, and their sources of income are work for hire $(23.3 \%)$ as well as disability and old-age pensions (18.5), since agricultural activity is the chief source of income for a mere $8 \%$ of farms.

Type 13 has mainly developed in areas surrounding type 17 from the north in Małopolska and Subcarpathia, and to a lesser extent in Silesia and Lublin region. It is scattered in small clusters, or occurs in single communes. Employment per unit area is high - 71.1 persons /100 ha AL. More than $75 \%$ of farm heads have no agricultural education. Their age structure is unfavourable, and more than $37 \%$ of holdings are run by women. Cereals predominate in the sown area (68\%). In animal production the best developed is poultry husbandry, especially hens and ducks. Over $41 \%$ of holdings operate to satisfy the farmers' own needs, hence their chief sources of income are work for hire as well as disability and old-age pensions.

Type $\mathbf{1 4}$ is characteristic almost exclusively of Silesia, especially of its Upper Silesian Basin. Its genesis is similar to that of type 15. Its origins go back to the first half of the 19th century, and its location until the end of the First World War in the former Prussian partition caused its development to be faster, which naturally translated into the dynamics of change in the agriculture of this area. The high level of industrialisation and urbanisation has caused the agriculture of this type to show the lowest share of individually-owned holdings in the country. In vegetable production cereals predominate $(77.5 \%)$, with a significant share of rape. Of major importance are also crops under glass. In animal production the raising of hens figures most prominently because of the absorptive market. Their number per 100 ha AL was more than four times higher than the national average ${ }^{34}$. The chief sources of income are work

344,503 hens, the national average being 1,000 . 
for hire $(27.8 \%)$ as well as disability and old-age pensions $(21.5 \%)$. Agricultural production is the chief source for a mere $5.1 \%$ of holdings.

Type 15 is characteristic of almost the entire area of the Subcarpathian Basins and the Beskids in Małopolska and Subcarpathia. It also occurs sporadically in single communes of Świętokrzyska Land. This type has largely developed in areas with favourable soil conditions. It shows a high share of individually-owned holdings. As a rule, those are very small farms, their average area amounting to 3.4 ha AL. This is the region of traditional family farmland divisions and sparse land resources owned by the Treasury. This faulty size structure is corroborated by an unusually high employment per 100 ha AL - 105 persons. This type is characterised by the highest proportion of holdings run by persons with no agricultural education. There is a high proportion of women running farms $38.8 \%{ }^{35}$. What is astonishing is the fact that this unusually high employment is accompanied by the highest level of endowment with tractors in the country - 18.9 per 100 ha AL. A characteristic of cattle husbandry is a high proportion of cows in a herd $-61.6 \%$ (while the stocking rate is low 25.1 head /100 ha AL). A mere $6.1 \%$ of holdings are involved in commodity production, while $50.8 \%$ produce mainly to satisfy their own needs. This is the type of agriculture in which holdings derive the highest proportion of their income (at the national scale) from work for hire $(34 \%)$ as well as disability and old-age pensions (26.3\%), and a mere $6.5 \%$ from agricultural activity.

Type 16 can be found in two major clusters. One is located in the eastern part of Silesia and the neighbouring small north-western fragment of Małopolska. It embraces the communes of the historical Dąbrowski Basin situated in the former Russian partition. The other cluster is situated in the northern part of Świętokrzyska Land and embraces communes of the historical Old Polish Basin. Because of mineral raw materials occurring here, the industrialisation of this area started already in the 19th century. This was the chief factor of the transformation of agriculture. Traces of those processes can be found even today. This concerns especially the size of the holdings. Their mean area (3.2 ha AL) is the smallest among the

35 The national mean being $29 \%$. types distinguished in this study. Due to the small number of holdings, their land is largely consolidated. This type is characterised by a specific structure of farmland. There is a high proportion of meadows (28.1\%) and fallow land $(10.1 \%)$, and a low one of arable land (33\%). As to vegetable production, a big role among field crops is played by potatoes $(10.8 \%)$ and crops under glass (1,957.4 m /100 ha of arable land). The level of animal production is low, only poultry raising and bee-keeping are slightly better developed. There is a very high proportion of holdings that do not conduct agricultural activity $(42.3 \%)^{36}$, and of those that do, commodity production is the chief line for only $9.5 \%$. Hence a mere $2.5 \%$ of farms report agriculture as the main source of their earnings. Equal sources of income are work for hire as well as disability and old-age pensions - in both cases the indicators exceed $21 \%$.

\section{Types of agriculture with a large share of large-scale farms and various ownership forms}

Type 17 was shaped to the greatest extent by features characterising property relations and spatial organisation of farms. Other characteristics were of minimum significance or neutral. The only significant role here was played by the concentration of cattle on farms breeding those animals at a large scale. This type can be found exclusively in four north-western regions ${ }^{37}$, where it forms large compact clusters (Fig. 3). Those were areas where state farms played a big role before the systemic changes of 1989 . Hence, in this type the Treasury still has the highest share in farmland ownership $(22.6 \%)^{38}$. The liquidation of state agriculture and the release of large resources of farmland connected with it cause this type to have a high proportion of large-lot holdings belonging to commercial companies $(8.5 \%)$. Besides, what distinguishes it from the other types is the highest average size of farms (26.1 ha AL). In the structure of crops, cereals figure most prominently $(6.4 \%)^{39}$, with a high proportion of rape $(13.5 \%)$. A characteristic feature

\footnotetext{
The national average being $17 \%$.

37 Apart from this area, this type occurs in a single commune in Lublin region.

38 The national mean being $8.5 \%$.

39 Without oats.
} 
of this type is the high concentration of cows on the farms that run their large-scale rearing. The breeding of turkeys is also of great importance, especially in Warmia-Mazuria and Lubusz Land. More than $81 \%$ of holdings included in this type conduct agricultural activity oriented towards commodity production ${ }^{40}$.

Type 18, like type 17, has developed in areas that were part of the German Reich until the end of the Second World War. After the war, with the limitations imposed on individually-owned farms, agriculture of the state sector came to the fore. The decisive factors were natural determinants: fertile soils and favourable climatic conditions. This type occurs in two extensive clusters. The bigger one embraces almost the entire Silesian Lowland in the regions of Lower Silesia and Opole. The smaller one has developed in the south-western part of West Pomerania. Its ownership structure and the average size of holdings (20.9 ha) are similar to those in type 17. It is characterised by the greatest fragmentation of farmland of all the types distinguished. In 2010, 61.8\% of agricultural land belonged to holdings that had it in more than 10 separate pieces, and in a dozen or so territorial units this indicator exceeded $70 \%$ or even $80 \%$. The number of people working in agriculture per 100 ha AL is low for Polish conditions, the average being 14.2 persons ${ }^{41}$. This type stands out for the highest use of artificial fertilisers, at $177.4 \mathrm{~kg}$ of a pure NPK component per 1 ha AL. Favourable natural conditions have caused farms to specialise mostly in vegetable production, while the level of animal production is very low. Among field crops, those leading in the sown area are wheat $(38.7 \%)$, rape $(22.6 \%)$, barley $(8.9 \%)$, and maize grown for seeds $(8.3 \%)$. The values of variables characterising their productive effects oscillated around national means.

The genesis of type $\mathbf{1 9}$ is similar to the two previous ones. It has developed in worse natural conditions. It forms three major clusters. The biggest one is located in Lower Silesia, where it embraces communes situated in the Sudeten, from which its western part passes into the lowland areas of south-western Lubuska Land. A smaller cluster has developed in the south-eastern part

\footnotetext{
$40 \quad 20.9 \%$ conduct exclusively commodity production.

41 In 2010 the national mean was 27.3 persons per 100 ha AL.
}

of Poland, where it embraces communes in the Bieszczady and the Niski Beskid Mountains. Those were the areas where the so-called "Action Vistula" 42 was carried out in the years 1947-1950 followed by mass deportation of the Ruthene population living there. For a few years those areas were uninhabited, and it was only in the mid-1950s that the army started to develop them again. One of the forms of development was the organisation of military holdings that survived until the systemic changes of 1989 . The third cluster of this type embraces communes in the lower section of the Odra valley. The indicators characterising the ownership structure and spatial organisation of type 19 are generally higher or close to the mean values for Poland. In other parts of Poland this type appears in small clusters or in single communes. Farms in this type are poorly equipped with the means of production. The level of agricultural education of farm operators and their ages are lower than the national average. Its characteristic features are a low proportion of arable land $(42.3 \%)$ and a high one of permanent grassland $(30.1 \%)$. Predominant among field crops are cereals, but, their significance is lower than in the other types (60.1\% of the sown area). The low level of vegetable and animal production clearly shows in the income structure of farms. A mere $12.4 . \%$ of them declared more than $50 \%$ of their earnings to derive from agricultural activity. What played a great role in them was work for hire $(24.8 \%)$ as well as disability and old-age pensions $(17.9 \%)$.

\section{Types of agriculture with different genesis and domination of private property}

Type 20 has developed in the greatest number of territorial units (769), most of them being towns of various sizes (590). They are scattered all over Poland. Rural units are also scattered, but occur in small clusters. They have usually formed in areas with large woodland complexes ${ }^{43}$, a high proportion of wetlands, and advanced urbanisation processes. Despite such large differences,

42 A military pacification action carried out in south-eastern Poland against the Ukrainian Insurgent Army (Action Vistula... 2006, Koprowski 2016, Motyka 2011, Ziemiec 2017).

43 In these areas, rural settlement developed on forest clearing or outskirts of forest complexes. 
this type has many common features. Marked differences can only be found in some of the variables considered in the research.

In the ownership structure individually-owned farms predominate $(70.1 \%)^{44}$, followed by property performing housing-recreational-service functions $(11.3 \%)$ and by Treasury land (7.3\%). Employment per 100 ha AL is 26.5 persons, lower than the national mean. The age structure of farm operators is worse than the national average, but they are better educated. Equipment with the means of production varies. It is worse in the case of vegetable production, but better in the husbandry of dairy cattle. As to the crop structure, there are small differences between rural units and towns. But there is a clear difference in the area of crops under glass ${ }^{45}$. The husbandry of cattle and swine is poorly developed, especially in towns ${ }^{46}$, where it is restricted by administrative regulations. There are also differences in the sources of income. In towns it mainly comes from work for hire $(23.7 \%)$ as well as disability and old-age pensions $(17.3 \%)^{47}$, and in rural areas, from work for hire $(26.44 \%)$, farming $(24.85 \%)$ as well as disability and old-age pensions $(14.8 \%)$.

\section{Conclusion}

The research aimed to find a synthetic approach to the characteristics of agriculture, defined by a large number, high complexity and diversity of its inter-related elements. The intensity of these elements is spatially heterogenous as the result of the impact of various conditions, both local and global. These features of agriculture decided about an attempt to use spatial econometric methods: spatial autocorrelation proposed by Moran (1950), and its extension to the LISA method by Anselin (1995).

These methods, combined with well-known classification methods, were used for the

44 The average value of this indicator in rural areas was $76.3 \%$, and in cities $62 \%$.

45 In cities, it amounted to 2,300.8 $\mathrm{m}^{2} / 100$ ha of arable land, and in rural areas $-539.1 \mathrm{~m}^{2} / 100$ ha of arable land.

46 The cattle density per 100 ha of agriculture land was 15.1, including cows 6.1.

47 Revenue from agriculture $10.5 \%$ identification of types of agriculture. The attempts at the identification of the types of agriculture made so far have been based on a small number of diagnostic variables. The methods of spatial econometrics and classification applied in this work do not limit the spatial scale and the number of analysed variables. However, the barrier is the availability of a full database of diagnostic variables for all spatial units being analysed. In the authors' opinion the results achieved with the use of these methods are satisfactory. The main advantage of these methods is that they take into account the occurrence of spatial dependence effects and the similarity of neighbouring areas. This approach, although widely present in many geographic and economic disciplines, has not received yet much attention in spatial research of agriculture.

It is also worth noting that the applied methods make it possible in the final stage of the analysis to group the synthetic indicators obtained for territorial units into sets (types) of varying degrees of similarity. The most optimal was to divide the set of 3,069 territorial units into 20 groups with a high degree of similarity. These groups are called "types".

The analysis of each of the distinguished types showed their characterological differences, as well as the varied significance of diagnostic variables in their structure. The regional spatial distribution of the identified types is a new approach, which in a synthetic manner confirms the differences in Polish agriculture at the same time taking into account the similarities in neighbouring units.

The conducted analysis revealed that nowadays the most numerous groups among the types (16) identified in Poland are those characterised by an advantage or a large share of private farms (large-scale commercial farming - 5, horticultural farming - 1, medium-scale commercial farming 4 and semi-subsistance farming - 6). Only three types of agriculture are characterised by large share of big farms representing various forms of ownership (medium-scale and semi-subsistance farming) and one was identified as a type of various genesis (semi-subsistance farming). The conditions of agricultural farming changed at the turn of 21st century, which obviously influenced the shaping of agriculture types. However, as in the last typology made for individual farming at 
the end of the 1980s, a large spatial diversification of the distinguished types was stated - Polish farming is still very diverse. Moreover, spatial distribution of types still refers to historical determinants as well as natural and socio-economic conditions and local spatial relationships.

Characteristics of identified types and spatial distribution can be of major utilitarian importance for spatial planning authorities creating regional agricultural development. Moreover, the indication of the importance of the analysed diagnostic variables for particular types makes it easier to select the appropriate tools controlling agriculture and to develop a regionally diversified strategy for further development of agriculture.

\section{Acknowledgments}

The authors would like to thank Mrs. Hanna Jefimowicz for preparing maps in this article.

\section{References}

Action Vistula 1947, 2006. Institute of National Remembrance, Warsaw-Kiev.

Agricultural typology and land use, 1973. Reeds L.G. (ed.), Commission of the International Geographical Union. McMaster University. Ontario.

Agricultural typology and land utilization, 1975. Vanzetti C. Verona (ed.).

Aitchison J.W., 1986/2014. Classification of agricultural systems. In: Pacion M. (ed.), Progress in agricultural geography. Routledge Revivals: 38-69.

Aitchison J.W., 1992/2014. Farm types and agricultural regions. In: Bowler I.R. (ed.), The geography of agriculture in developed market economies. Routledge Revivals: 109-133.

Anselin L., 1988. Spatial econometrics: Methods and models. Kluwer, Dordrecht.

Anselin L., 1995. Local indicators of spatial association-LISA. Geographical Analysis 27: 93-115.

Atlas rolnictwa Polski (Atlas of Polish agriculture), 2010. Bański J. (ed.), IGiPZ PAN, Warszawa.

Atlas obszarów wiejskich w Polsce (Atlas of rural areas in Poland), 2016. Bański J. (ed.), IGiPZ PAN. Warszawa.

Bański J., 1991. Typy rolnictwa Jemenu Południowego (Types of agriculture in South Yemen). Przeglad Geograficzny 63(3-4); 307-324.

Bański J., 2007a. Geografia rolnictwa Polski (Geography of Polish agriculture). PWE, Warszawa.

Bański J., 2007b. Nature conditions of farming in Poland. In: Grykień R., Hasiński W. (eds), Environmental conditioning of rural areas development. Committee of Rural Areas of the Polish Geographical Society and Rural Areas Study Group S. Leszczycki Institute of Geography and Spatial Organisation Polish Academy of Sciences. Rural Studies 12: 9-18.

Bertaglia M., Joost S., Roosen J., Econogene Consortium, 2007. Identifying European marginal areas in the context of local sheep and goat breeds conservation: A geographic information system approach. Agricultural Systems 94: 657-670.

Blazy J.M., Ozier-Lafontaine H., Doré T., Thomas A., Wery J., 2009. A methodological framework that accounts for farm diversity in the prototyping of crop management systems. Application to banana-based systems in Guadeloupe. Agricultural Systems 101: 30-41.

Biegajło W., 1968. Types of agriculture in north-eastern Poland (Bialystok voivodship). Geographia Polonica 14: 275282.

Biegajło W., 1973. Typologia rolnictwa na przykładzie województwa białostockiego (Typology of agriculture on the example of Białostockie Voivodeship). Prace Geograficzne 100: 163.

Carmona A., Nahuelhual L., Echeverría C., Báez A., 2010. Linking farming systems to landscape change: An empirical and spatially explicit study in southern Chile. Agriculture, Ecosystems \& Environment 139: 40-50.

Charakterystyka rolniczej przestrzeni produkcyjnej Polski (Characteristics of the Polish agricultural production space), 2003. Ciołkosz A. (ed.), Główny Urząd Statystyczny (Statistics Poland), Warszawa.

Cliff A.D., Ord J.K., 1973. Spatial autocorrelation. Pion, London.

Czapiewska G., 2003. Historyczne uwarunkowania rozwoju rolnictwa uspołecznionego na Pomorzu Środkowym (Historical determinants of the development of socialised agriculture in Central Pomerania). Stupskie Prace Geograficzne 1: 51-67.

Falkowski J., 1977. Próba typologii i regionalizacji rolnictwa aglomeracji bydgosko-torunskiej (An attempt at the typology and regionalisation of the agriculture of the Bydgoszcz-Toruń agglomeration). Przeglad Geograficzny 49(4): 713-730.

Falkowski J., Kostrowicki J., 2001. Geografia rolnictwa świata (Geography of global agriculture). Wydawnictwo Naukowe PWN, Warszawa.

Gałczyńska B., 1982. Typologia rolnictwa Bułgarii (Typology of Bulgarian agriculture). Przeglad Geograficzny 54(4): 551-570.

Gałczyńska B., 1985. Struktura przestrzenna rolnictwa Bułgarii (Spatial structure of Bulgarian agriculture). Zagadnienia Ekonomiki Rolnej 1: 124-126.

Getis A., Aldstadt J., 2004. Constructing the spatial weights matrix using a local statistic. Geographical Analysis 36: 90-104.

Gawryszewski A., 2005. Ludność Polski w XX wieku (The population of Poland in the 20th century). Monografie 5 Instytut Geografii i Przestrzennego Zagospodarowania PAN, Warszawa.

Głębocki B., 1979. Typologia rolnictwa woj. Kaliskiego (Typology of agriculture in Kalisz Voiovodeship). In: Chojnicki Z. (ed.), Struktura i funkcje układów przestrzenno-ekonomicznych (Structure and functions of spatio-economic patterns). Wydawnictwo Naukowe UAM, Poznań: 123130.

Głębocki B., 1986. Delimitacja i analiza struktur typologicznych rolnictwa województwa poznańskiego (Delimitation and analysis of the typological structures of Poznań Voivodeship). In: Czyż T. (ed.), Metody badania struktury regionalnej (Research methods of the regional structure). UAM w Poznaniu. Poznań, Seria Geografia 32: 79-99. 
Głębocki B., 2000. Changes in the agrarian structure of Polish agriculture in the years 1990-1996. In: Głębocki B. (ed.), Poland's agrarian structure in the period of political and economic transformation. Bogucki Wydawnictwo Naukowe. Poznań: 9-74.

Głębocki B., 2006. Changes in the agrarian structure of Poland in 1990-2002. Quaestiones Geographicae 25(B): 37-46.

Głębocki B., 2007a. Użytkowanie ziemi i zmiany w środowisku przyrodniczym (Land-use and changes in the natural environment). In: Rogacki H. (ed.), Geografia spoteczno-ekonomiczna Polski (Socio-economic geography of Poland). PWN, Warszawa: 70-84.

Głębocki B., 2007b. Rolnictwo (Agriculture). In: Rogacki H. (ed.), Geografia społeczno-ekonomiczna Polski (Socio-economic geography of Poland). PWN, Warszawa: 185-271.

Głębocki B., 2007c. Landed property of churches and denominational associations in Poland. Quaestiones Geographicae 29(2): 39-54.

Głębocki B., 2014. Zmiany w strukturze agrarnej polskiego rolnictwa w latach 2002-2012 (Changes in the agrarian structure of Polish agriculture in 2002-2012). In: Głębocki B. (ed.), Zróżnicowanie przestrzenne rolnictwa. Powszechny Spis Rolny (Spatial differences in agriculture. National Agricultural Census) 2010. Główny Urząd Statystyczny (Statistics Poland), Warszawa: 14-71.

Gregor H.F., 1970. Geography of agriculture: Themes in research. Prentice-Hall, Englewood Cliffs, New Jersey.

Grigg D., 1966. The geography of farm size a preliminary survey. Economic Geography 42: 205-235.

Grigg D., 1969. The agricultural regions of the world. Review and reflections. Economic Geography 45(2): 95-132.

Grigg D., 1974. The agricultural systems of the world: An evolutionary approach. Cambridge University Press, Cambridge.

Grigg D., 1995. An introduction to agricultural geography. Routledge, London and New York.

Grykień S., 2005. Transformacja rolnictwa w krajach Europy Środkowo-Wschodniej (Transformation of agriculture in the countries of East-Central Europe). Przeglad Geograficzny 77(2): 213-233.

Hudson D.P., White J.W., 2007. Use of spatial analyses for global characterization of wheat-based production systems. Journal of Agricultual Science 145: 115-125.

Iraizoz B., Gorton M., Davidova S., 2007. Segmenting farms for analysis agricultural trajectories: A case study of the Navarra region in Spain. Agricultural Systems 93: 143-169.

Jezierski A., Leszczyńska C., 2003. Historia gospodarcza Polski (An economic history of Poland). Wydawnictwo Key Text, Warszawa.

Jezierska-Thole A., Janzen J., Rudnicki R., 2014. Agrarian-economic structure of agricultural holdings in Poland and East Germany: Select elements of comparative analysis. Quaestiones Geographicae 33 (2): 87-101.

Kaliński J., Noniewicz C., 2015. Historia gospodarcza Polski XIX $i$ XX wieku (An economic history of Poland of the 19th and 20th century). Wydawnictwo Uniwersytetu w Białymstoku, Białystok.

Kłodziński M., Wilkin J., 1998. Development of Poland's rural areas in light of its future membership of the European Union. Wieś i Rolnictwo: 89-101.

Kopiński J., Krasowicz S., 2010. Regionalne zróżnicowanie warunków produkcji rolniczej w Polsce (Regional differences in the conditions of agricultural production in Poland). Studia i Raporty IUNiG-PIB 22: 9-31.
Koprowski M.A., 2016. Akcja "Wista" Krwawa Wojna z OUNUPA (Action 'Vistula'. Bloody war against OUN-UPA). Replika, Zakrzewo.

Kossowski T., 2009. Metody i modele ekonometrii przestrzennej (Methods and models of spatial econometrics). In: Zwoliński Z. (ed.), GIS - platforma integracyjna geografii (GIS - geographical integration platform). Bogucki Wydawnictwo Naukowe, Poznań: 145-165.

Kossowski T., 2018. Spatial dependence: How can we identify and measure it? In: Kuttor D. (ed.), Visegrad mosaic - new colours and old contours. Observing and understanding the spatial features of socio-economic processes in East Central Europe. Miskolci Egyetem, Miskolc: 39-60.

Kostrowicki J., 1964, Geographical typology of agriculture in Poland. Methods and Problems. Geographia Polonica 1: 111-146.

Kostrowicki J., 1968, Agricultural typology, agricultural regionalization, agricultural development. Geographia Polonica 14: 265-274.

Kostrowicki J., 1969. Typologia rolnictwa - założenia, kryteria, metody (Agricultural typology - principles, criteria, methods and techniques). Przeglad Geograficzny 41(4): 599-621.

Kostrowicki J., 1970. Types of agriculture in Poland. A preliminary attempt at a typological classification. Geographia Polonica 19: 99-110.

Kostrowick J., 1972. Próba typologii rolnictwa świata (An attempt at the typology of the world agriculture) Przeglad Geograficzny 44(3): 395-435.

Kostrowicki J., 1977. Agricultural typology concept and method. Agricultural Systems 2(1): 33-45.

Kostrowicki J., 1978. Typy rolnictwa Polski (Agriculture types in Poland). In: Berezowski S. (ed.), Geografia ekonomiczna Polski (An economic geography of Poland). PWN, Warszawa: 375-383.

Kostrowicki J., 1979. Twelve years' activity of the IGU Commission on Agricultural Typology, Geographia Polonica 40: 235-260.

Kostrowicki J., 1991. Trends in the transformation of European agriculture. In: Brouwer F.M., Thomas A.J., Chadwick M.J. (eds), Land use changes in Europe. The GeoJournal Library 18. Springer, Dordrecht: 21-47.

Kostrowicki J., Szczęsny R., 1978. Typy rolnictwa (Types of agriculture). In: Kostrowicki J. (ed.), Przemiany struktury przestrzennej rolnictwa Polski 1950-1970 (Changes in the spatial structure of Polish agriculture in 1950-1970). Prace Geograficzne 127. IGiPZ PAN, Warszawa: 428-508.

Kostrowick J., Szyrmer J.H., 1990. Typologia rolnictwa. Koncepcja i metoda (Typology of agriculture. The conception and the method). IGiPZ PAN, Warszawa.

Köbrich C., Rehman T., Khan M., 2003. Typification of farming systems for constructing representative farm models: Two illustrations of the application of multi-variate analyses in Chile and Pakistan. Agricultural Systems 76: 141-157.

Kulikowski R., 1986. Wykorzystanie rolniczej przestrzeni produkcyjnej $\mathrm{w}$ Polsce - próba analizy przestrzennej (The use of agricultural production space in Poland an attempt at spatial analysis). Przeglad Geograficzny 58 (1-2): 191-202.

Kulikowski R., 2007a. Influence of natural condition on spatial differentiation of Polish agriculture. In: Grykień R., Hasiński W. (eds), Environmental conditioning of rural areas development. Committee of Rural Areas Polish Geographical Society and Rural Areas Study Group S. 
Leszczycki Institute of Geography and Spatial Organisation Polish Academy of Sciences, Warsaw. Rural Studies 12: 19-31.

Kulikowski R., 2007b. Wpływ warunków przyrodniczych na zróżnicowanie przestrzenne rolnictwa w Polsce (Impact of natural conditions on the spatial diversity of agriculture in Poland). Studia Obszarów Wiejskich 12: 19-31.

Matusik M., 1973. Próba typologii i regionalizacji rolnictwa na obszarze Dolnego Powiśla (An attempt at the typology and regionalisation of agriculture in the area of Lower Powiśle). Prace Geograficzne 102: 153.

Mądry W., Gozdowski D., Roszkowska-Mądra B., Hryniewski R., 2011. Typologia systemów produkcji rolniczej: koncepcja, metodologia i zastosowanie (Typology of agricultural production systems: Conception, methodology and application). Fragmenta Agronomica 28(3): 70-81.

Moran P.A.P., 1950. Notes on continuous stochastic phenomena. Biometrika 37: 17-23.

Morawski W., 2011. Dzieje gospodarcze Polski (An economic history of Poland). Difin, Warszawa

Musiał W., 2012. Uwarunkowania gospodarowania ziemią rolniczą $\mathrm{w}$ regionach rozdrobnionych agrarnie (wybrane aspekty) (Conditions for the management of agricultural land in agrarian fragmented regions (selected aspects)). In: Rosner A. (ed.), Rozwój wsi i rolnictwa w Polsce. Aspekty przestrzenne i regionalne (Development of countryside and agriculture in Poland). IRWiR PAN. Warszawa: 179-206.

Olszewski T., 1985. Geografia rolnictwa Polski (Geography of Polish agriculture). PWE, Warszawa.

Przestrzenna transformacja struktury agrarnej a wielofunkcyjny rozwój wsi w Polsce (Spatial transformation of the agrarian structure and multifunctional development of rural areas in Poland), 1998. Głębocki B. (ed.), Bogucki Wydawnictwo Naukowe, Poznań.

Polska wieś 2016. Raport o stanie wsi (Polish countryside 2016. Report on the state of the countryside), 2016. Wilkin J., Nurzyńska I. (eds), FDPA. Wydawnictwo Naukowe Scholar. Warszawa.

Rolnictwo na obszarach specyficznych (Agriculture in specific areas), 2013. Matyka M. (ed.), Powszechny Spis Rolny (National Agricultural Census) 2010. Główny Urząd Statystyczny (Statistics Poland). Warszawa.

Rudnicki R., 2010. Zróżnicowanie przestrzenne wykorzystania funduszy Unii Europejskiej przez gospodarstwa rolne w Polsce w latach 2004-2006 (Spatial differences in the use of EU funds by agricultural holdings in Poland in 2004-2006). Seria Studia i Prace z Geografii i Geologii 17. Bogucki Wydawnictwo Naukowe, Poznań.

Rudnicki R., 2013a. Spatial differences in the use of European funds by agricultural holdings in Poland in the years 2002-2010. Studia Regionalia KPZK PAN 36: 71-87.

Rudnicki R., 2013b. Spatial differences in the number of applications for payments under the UE Common Agricultural Policy submitted by agricultural holdings in Poland over the years 2002-2010. Quaestiones Geographicae 32(4): 15-31.

Rudnicki R., 2014. Analiza absorpcji środków WPR i ich wpływu na zmiany strukturalne $\mathrm{w}$ rolnictwie polskim (Analysis of apsorption of CAP funds and their influence on structural changes in Polish agriculture). In: Głębocki B. (ed.), Zróżnicowanie przestrzenne rolnictwa. Powszechny Spis Rolny 2010 (Spatial differences in agriculture. Na- tional Agricultural Census 2010). Główny Urząd Statystyczny (Statistics Poland). Warszawa: 441-463.

Scott P., 1983. The typology of Australian agriculture. Geographia Polonica 40: 113-131.

Singh V.R., 1979. Agricultural typology of India. Geographia Polonica 46: 7-19.

Sroka W., 2015. Historyczne uwarunkowania dominacji drobnych gospodarstw rolnych $\mathrm{w}$ rolnictwie Europy Środkowo-Wschodniej (Historical determinants of the domination of small farms in the agriculture of East-Central Europe). Problemy Drobnych Gospodarstw Rolnych 4: 61-73.

Stankowski W., 2007. Przyrodnicze podstawy funkcjonowania społeczeństwa i gospodarki (The environmental basis for the functioning of society and the economy). In: Rogacki H. (ed.), Geografia społeczno-ekonomiczna Polski (Socio-economic geography of Poland). PWN, Warszawa: 36-69.

Stola W., 1970. Procedure of agricultural typology. The case of Ponidzie, Central Poland. Geographia Polonica 19: 111118.

Stola W., 1972. Typologia rolnictwa mezoregionu. Porównanie wyników zastosowania dwóch metod (Typology of mesoregion agriculture. Comparison of the results of two methods). Przeglad Geograficzny 44(1): 85-95.

Stola W., 1974. Etudes regionales sur la typologie de 1 'agriculture polonaise. Geographia Polonica 29: 231-243.

Stola W., 1977. Próba zastosowania metod typologicznych do badań porównawczych rozwoju rolnictwa Belgii i Polski (An attempt to apply typological methods in the comparative studies of the development of Belgian and Polish agriculture). Przegląd Geograficzny 49(4): 757-771.

Stola W., Szczęsny R., 1976. Geografia rolnictwa Polski (Geography of Polish agariculture). WSiP, Warszawa.

Szczęsny R., 1978, Changes and trends in the spatial pattern of types of indivdual agriculture in Poland. 1960-1970. In: Kostrowicki J., Tyszkiewicz W. (eds), Transformations of rural areas. Proceedings of the 1st Polish-Yugoslav Seminar. Polish Academy of Sciences, Institute of Geography and Spatial Organisation, Warsaw: 155-164.

Szczęsny R., 1981. Transformations of agricultural types in Poland 1970-1976. In: Noor Mohammad (ed.), New Delhi, Perspectives in Agricultural Geography 1: 209-228.

Szczęsny R., 1982. Typy rolnictwa Szwajcarii (Agriculture types in Switzerland). Przeglad Geograficzny 54(4): 511531.

Szczęsny R., 1988. Przemiany struktury przestrzennej rolnictwa Polski w latach 1970-1980 (Changes in the spatial structure of agriculture in Poland in 1970-1980). Przestrzenne zróżnicowanie typów rolnictwa. (Changes of the Spatial Structure of Polish Agriculture in the years 1970-1980). Prace habilitacyjne IGiPZ PAN, Ossolineum, Wrocław.

Szczęsny R., Szczęsny R., 1996. Typy rolnictwa i gospodarka żywnościowa (Types of agriculture and the food industry). In: Altas Rzeczypospolitej Polskiej (Atlas of the Republic of Poland). Główny Geodeta Kraju, Warszawa: 81.11.

Szyrmer J., 1984. Essai de la typologie de l'agriculture autogérée algérienne. Geographia Polonica 50: 151-168.

Tiefelsdorf M., Griffith D.A., Boots B., 1998. A variance stabilizing coding scheme for spatial link matrices. Environment and Planning A 31: 165-180.

Tittonell P., Muriuki A., Shepherd K.D., Mugendi D., Kaizzi K.C., Okeyo J., Verchot L., Coe R., Vanlauwe B., 2010. The diversity of rural livelihoods and their influence on soil 
fertility in agricultural systems of East Africa - A typology of smallholder farms. Agricultural Systems 103: 83-97.

Tobler W., 1970. A computer model simulating urban growth in Detroit region. Economic Geography 46(2): 234-240.

Tschudi B., Johanson H., 1983. Types of agriculture in Norway by the typogram method. Geographia Polonica 46: 83-91.

Tyszkiewicz W., 1977. Typy rolnictwa Macedonii jako przykład rolnictwa światowego (Types of Macedonian agriculture as an example of world agriculture). Przeglad Geograficzny 49(4): 781-804.

Tyszkiewicz W., 1979. Agricultural typlogy of the Thracian Basin, Bułgaria, as a case of the typology of world agriculture. Geographia Polonica 40: 171-186.

Tyszkiewicz W., 1982. Zastosowanie metod typologicznych do badan rolnictwa Szwecji (The application of the typo- logical methods to the studies of Swedish agriculture). Przeglad Geograficzny 53(4): 551-570.

Tyszkiewicz W., 1986. Typological study of Swedish agriculture. In: Singh V., Singh N.K., (eds), Perspectives in agricultural typology. Varanasi: 39-54.

Whittlesey D., 1936 Major agricultural regions of the Earth. Annals of the Association of American Geographers 26(4): 149-240.

Woś A., 1998. Rolnictwo polskie w okresie transformacji systemowej (Polish agriculture in the period of the systemic transformation). IERiGŻ, Warszawa.

Wysocki F., 2010. Metody taksonomiczne w rozpoznawaniu typów ekonomicznych rolnictwa i obszarów wiejskich (Taxonomic methods in recognising economic types of agriculture and rural areas). Wydawnictwo Uniwersytetu Przyrodniczego w Poznaniu, Poznań.

Appendix 1. Typological features in 2010.

\begin{tabular}{|c|c|c|c|c|c|}
\hline $\begin{array}{c}\text { Land tenure } \\
\text { system (2012) and } \\
\text { organisation of } \\
\text { production space } \\
(2010)\end{array}$ & $\begin{array}{l}\text { Labour resources } \\
\text { and quality }\end{array}$ & $\begin{array}{l}\text { Means of } \\
\text { production }\end{array}$ & $\begin{array}{c}\text { Natural resources } \\
\text { and structure of } \\
\text { crops }\end{array}$ & $\begin{array}{l}\text { Proportion and } \\
\text { concentration } \\
\text { of animal } \\
\text { husbandry }\end{array}$ & $\begin{array}{l}\text { Effects of } \\
\text { agricultural } \\
\text { production }\end{array}$ \\
\hline $\begin{array}{l}\text { 1- percentage } \\
\text { of the Treasury } \\
\text { property }\end{array}$ & $\begin{array}{l}11 \text { - number of } \\
\text { working per } 100 \\
\text { ha of agricultural } \\
\text { land }\end{array}$ & $\begin{array}{l}21 \text { - number of } \\
\text { cereal combine } \\
\text { harvesters per } 100 \\
\text { ha of agricultural } \\
\text { land }\end{array}$ & $\begin{array}{l}30 \text { - percentage } \\
\text { of arable land in } \\
\text { agricultural land }\end{array}$ & $\begin{array}{l}48-\text { number of } \\
\text { horses per } 100 \\
\text { ha of agricultur- } \\
\text { al land, }\end{array}$ & $\begin{array}{l}63 \text { - percentage } \\
\text { of farms in which } \\
\text { more than } 50 \% \\
\text { of farm income } \\
\text { comes from agri- } \\
\text { cultural activity }\end{array}$ \\
\hline $\begin{array}{l}2 \text { - percentage of } \\
\text { natural persons' } \\
\text { property (farms) }\end{array}$ & $\begin{array}{l}12 \text { - percentage of } \\
\text { people with high- } \\
\text { er education }\end{array}$ & $\begin{array}{l}22-\text { number of } \\
\text { potato combine } \\
\text { harvesters per } 100 \\
\text { ha of agricultural } \\
\text { land }\end{array}$ & $\begin{array}{l}31 \text { - percentage } \\
\text { of wasteland in } \\
\text { agricultural land }\end{array}$ & $\begin{array}{l}49 \text { - total num- } \\
\text { ber of cattle per } \\
100 \text { ha of agri- } \\
\text { cultural land, }\end{array}$ & $\begin{array}{l}\text { 64- percentage of } \\
\text { farms in which } \\
\text { more than } 50 \% \\
\text { of farm income } \\
\text { comes from hired } \\
\text { labour }\end{array}$ \\
\hline $\begin{array}{l}3 \text { - percentage of } \\
\text { natural persons' } \\
\text { property (building } \\
\text { lots) }\end{array}$ & $\begin{array}{l}13 \text { - percentage of } \\
\text { people with sec- } \\
\text { ondary education }\end{array}$ & $\begin{array}{l}23-\text { number of } \\
\text { beat combine } \\
\text { harvesters per } 100 \\
\text { ha of agricultural } \\
\text { land }\end{array}$ & $\begin{array}{l}32 \text { - percentage of } \\
\text { orchards in agri- } \\
\text { cultural land }\end{array}$ & $\begin{array}{l}50 \text { - number of } \\
\text { cows per } 100 \text { ha } \\
\text { of agricultural } \\
\text { land, }\end{array}$ & $\begin{array}{l}65 \text { - percentage } \\
\text { of farms in which } \\
\text { more than } 50 \% \\
\text { of farm income } \\
\text { comes from disa- } \\
\text { bility and old-age } \\
\text { pensions }\end{array}$ \\
\hline $\begin{array}{l}4 \text { - percentage of } \\
\text { farming coopera- } \\
\text { tives' property }\end{array}$ & $\begin{array}{l}14 \text { - percentage } \\
\text { of people with } \\
\text { post-primary vo- } \\
\text { cational education }\end{array}$ & $\begin{array}{l}24 \text { - number of } \\
\text { tractors per } 100 \\
\text { ha of agricultural } \\
\text { land }\end{array}$ & $\begin{array}{l}33 \text { - percentage of } \\
\text { house gardens in } \\
\text { agricultural land }\end{array}$ & $\begin{array}{l}51 \text { - percentage } \\
\text { of cows in herd, }\end{array}$ & $\begin{array}{l}66 \text { - percentage } \\
\text { of farms running } \\
\text { agricultural activ- } \\
\text { ity }\end{array}$ \\
\hline $\begin{array}{l}5 \text { - percentage } \\
\text { of churches and } \\
\text { denomination- } \\
\text { al associations' } \\
\text { property }\end{array}$ & $\begin{array}{l}15 \text { - percentage } \\
\text { of people with no } \\
\text { education }\end{array}$ & $\begin{array}{l}25 \text { - percentage } \\
\text { of farms raising } \\
\text { cows using churn } \\
\text { milking machines }\end{array}$ & $\begin{array}{l}34 \text { - percentage } \\
\text { of meadows in } \\
\text { agricultural land }\end{array}$ & $\begin{array}{l}52 \text { - number of } \\
\text { swine per } 100 \\
\text { ha of agricultur- } \\
\text { al land, }\end{array}$ & $\begin{array}{l}67 \text { - percentage } \\
\text { of farms not run- } \\
\text { ning agricultural } \\
\text { activity }\end{array}$ \\
\hline $\begin{array}{l}6 \text { - percentage } \\
\text { of companies' } \\
\text { property }\end{array}$ & $\begin{array}{l}16 \text { - mobile age } \\
\text { (up to } 44 \text { years } \\
\text { old) }\end{array}$ & $\begin{array}{l}\text { 26- percentage } \\
\text { of farms rais- } \\
\text { ing cows using } \\
\text { pipeline milking } \\
\text { machines }\end{array}$ & $\begin{array}{l}35 \text { - percentage of } \\
\text { pastures in agri- } \\
\text { cultural land }\end{array}$ & $\begin{array}{l}53 \text { - total num- } \\
\text { ber of poultry } \\
\text { per } 100 \text { ha of } \\
\text { agricultural } \\
\text { land, }\end{array}$ & $\begin{array}{l}68 \text { - percentage } \\
\text { of farms in which } \\
\text { final production } \\
\text { is fully commer- } \\
\text { cial }\end{array}$ \\
\hline
\end{tabular}


Appendix 1. continued

\begin{tabular}{|c|c|c|c|c|c|}
\hline $\begin{array}{c}\text { Land tenure } \\
\text { system (2012) and } \\
\text { organisation of } \\
\text { production space } \\
(2010)\end{array}$ & $\begin{array}{c}\text { Labour resources } \\
\text { and quality }\end{array}$ & $\begin{array}{l}\text { Means of } \\
\text { production }\end{array}$ & $\begin{array}{c}\text { Natural resources } \\
\text { and structure of } \\
\text { crops }\end{array}$ & $\begin{array}{l}\text { Proportion and } \\
\text { concentration } \\
\text { of animal } \\
\text { husbandry }\end{array}$ & $\begin{array}{l}\text { Effects of } \\
\text { agricultural } \\
\text { production }\end{array}$ \\
\hline $\begin{array}{l}7 \text { - percentage } \\
\text { of consolidated } \\
\text { agricultural land } \\
\text { in farms }\end{array}$ & $\begin{array}{l}17 \text { - mobile age } \\
\text { (up to } 34 \text { years } \\
\text { old) }\end{array}$ & $\begin{array}{l}27 \text { - percentage } \\
\text { of farms raising } \\
\text { cows using bucket } \\
\text { milk coolers }\end{array}$ & $\begin{array}{l}36 \text { - percentage } \\
\text { of wheat in sown } \\
\text { area }\end{array}$ & $\begin{array}{l}54 \text { - number of } \\
\text { hens per } 100 \text { ha } \\
\text { of agricultural } \\
\text { land }\end{array}$ & $\begin{array}{l}69 \text { - percentage } \\
\text { of farms in which } \\
\text { final produc- } \\
\text { tion is destined } \\
\text { exclusively for } \\
\text { self-supplying } \\
\text { farms }\end{array}$ \\
\hline $\begin{array}{l}8 \text { - percentage of } \\
\text { agricultural land } \\
\text { in farms with } \\
\text { more than } 10 \text { plots }\end{array}$ & $\begin{array}{l}18 \text { - non-mobile } \\
\text { age ( } 45-64 \text { years } \\
\text { old) }\end{array}$ & $\begin{array}{l}28 \text { - percentage } \\
\text { of farms raising } \\
\text { cows using tank } \\
\text { milk coolers, }\end{array}$ & $\begin{array}{l}37 \text { - percentage of } \\
\text { rye in sown area }\end{array}$ & $\begin{array}{l}55 \text { - number of } \\
\text { broilers per } 100 \\
\text { ha of agricultur- } \\
\text { al land }\end{array}$ & \\
\hline $\begin{array}{l}9 \text { - average area of } \\
\text { all farms in ha }\end{array}$ & $\begin{array}{l}19 \text { - post-working } \\
\text { age (over 65), }\end{array}$ & $\begin{array}{l}29 \text { - use of min- } \\
\text { eral (artificial) } \\
\text { fertilisers NPK in } \\
\text { pure component } \\
\text { in } \mathrm{kg} / 1 \text { ha of agri- } \\
\text { cultural land }\end{array}$ & $\begin{array}{l}38 \text { - percentage } \\
\text { of barley in sown } \\
\text { area }\end{array}$ & $\begin{array}{l}56 \text { - number of } \\
\text { turkeys per } 100 \\
\text { ha of agricultur- } \\
\text { al land }\end{array}$ & \\
\hline $\begin{array}{l}10 \text { - average area } \\
\text { of farms over } 1 \text { ha }\end{array}$ & $\begin{array}{l}20 \text { - percentage of } \\
\text { women managing } \\
\text { farms }\end{array}$ & & $\begin{array}{l}39 \text { - percentage of } \\
\text { triticale in sown } \\
\text { area }\end{array}$ & $\begin{array}{l}57 \text { - number of } \\
\text { geese per } 100 \text { ha } \\
\text { of agricultural } \\
\text { land }\end{array}$ & \\
\hline
\end{tabular}


Appendix 2. Features determining types of agriculture.

\begin{tabular}{|c|c|c|c|c|c|c|}
\hline \multirow[b]{2}{*}{$\begin{array}{l}\text { No. } \\
\text { of } \\
\text { type }\end{array}$} & \multirow[b]{2}{*}{$\begin{array}{c}\text { Land tenure } \\
\text { system (2012) } \\
\text { and organisation } \\
\text { of production } \\
\text { space (2010) }\end{array}$} & \multirow[b]{2}{*}{$\begin{array}{l}\text { Labour } \\
\text { resources and } \\
\text { quality }\end{array}$} & \multirow[b]{2}{*}{$\begin{array}{l}\text { Means of } \\
\text { production }\end{array}$} & \multicolumn{2}{|c|}{ Resources, crops and husbandry } & \multirow[b]{2}{*}{$\begin{array}{l}\text { Effects of } \\
\text { agricultural } \\
\text { production }\end{array}$} \\
\hline & & & & $\begin{array}{l}\text { Natural } \\
\text { resources and } \\
\text { structure of } \\
\text { crops }\end{array}$ & $\begin{array}{l}\text { Proportion and } \\
\text { concentration } \\
\text { of animal } \\
\text { husbandry }\end{array}$ & \\
\hline 1 & 2 & $14,16,17$ & 26,28 & $34,35,40,45$ & $49,50,60$ & 63,66 \\
\hline 2 & 2 & $13,14,16,17$ & $23,25,28,29$ & $30,44,45$ & $49,50,52,60$ & 63,66 \\
\hline 3 & 9,10 & 13,14 & $25,28,29$ & $30,38,39,42,44$ & 52,60 & 63 \\
\hline 4 & $6,9,10$ & 14 & $26,28,29$ & $30,36,42,44$ & 60 & 63 \\
\hline 5 & 2 & $14,16,17$ & & $37,39,40$ & 49,50 & 63,66 \\
\hline 6 & 7 & & 24 & 46,47 & & 68 \\
\hline 7 & & & 21,24 & 32,38 & 51 & \\
\hline 8 & 8 & & $21,25,29$ & 30,38 & 52 & \\
\hline 9 & 2,9 & 16,17 & $21,23,24$ & $30,36,38,44$ & & 66 \\
\hline 10 & 2 & & & $37,39,40$ & & \\
\hline 11 & & 15 & 24 & 37,39 & 58 & 65,69 \\
\hline 12 & 3 & $11,15,19,20$ & 24 & $34,39,43$ & 48,51 & $65,67,69$ \\
\hline 13 & 3 & 11,20 & 24 & 36 & 51,58 & 64,69 \\
\hline 14 & 3,7 & 11,20 & 21,24 & 38 & & $65,67,69$ \\
\hline 15 & 3,7 & $11,19,20$ & 24 & $34,36,43$ & 51 & 65,69 \\
\hline 16 & 3 & $11,15,19,20$ & 24 & 31,43 & & $65,67,69$ \\
\hline 17 & $1,6,9,10$ & & & $31,32,37,43$ & 60 & \\
\hline 18 & $1,6,8,10$ & & 29 & $30,36,41,42$ & & \\
\hline 19 & 1 & & & 34,35 & & \\
\hline 20 & & & No significant & tures in this type & & \\
\hline
\end{tabular}

Source: own calculations on the basis of data of the 2010 National Agricultural Census, Statistics Poland and the Head Office of Geodesy and Cartography in Warsaw. 